\title{
Expressões conceituais do insólito no espaço literário sul-americano
}

\author{
Expresiones conceptuales Del insólito en el espacio literario sudamericano
}

\author{
Luciana Helena Cajas Mazzutti \\ André Luis Mitidieri \\ Universidade Estadual de Santa Cruz - UESC - Ilhéus - Bahia - Brasil
}

\begin{abstract}
Resumo: Esta investigação pretende esclarecer o uso indiscriminado dos termos que, a princípio, "catalogavam" a obra literária hispano-americana e, de certa forma, corroboraram com o deslizamento que se instaurou na definição dos conceitos de Realismo Mágico, Realismo Maravilhoso e Fantástico. O estudo teórico-literário visa entender especialmente a incidência dessas duas últimas modalidades do Insólito na América do Sul, sem desconsiderar a cultura desse continente, mas associando-a ao mapeamento literário que, contudo, não nega zonas de contatos e diálogos. Buscamos, assim, articular uma discussão que, a partir, do enraizamento nos campos da crítica e da história literária, não só destaca a especial configuração do Insólito na literatura sul-americana, mas também estabelece a modalidade que contribui para com a visualização e a representação da diversidade cultural que the é própria. Valemo-nos de uma pesquisa com metodologia qualitativa de cunho bibliográfico que aspira analisar, caracterizar, definir e consignar diferenças pertinentes às modalidades insólitas em questão.
\end{abstract}

Palavras-chave: Fantástico. Insólito. Real Maravilhoso. Realismo Maravilhoso.

Resumen: Esta investigación pretende esclarecer el uso indiscriminado de los términos que, a principio, "catalogaban" la obra literaria hispano-americana; y, de cierto modo, corroboraron con el deslizamiento que se instauró en la definición de los conceptos del Realismo Mágico, Realismo Maravilloso y Fantástico. El estudio teóricoliterario visa entender especialmente la incidencia de esas dos últimas modalidades narrativas del Insólito en la América del Sur, sin desconsiderar la cultura de ese continente, pero asociándolo al mapeo literario que, no obstante, no niega zonas de contactos y diálogos. Buscamos, así, articular una discusión que, a partir, del enraizamiento en los campos de la crítica y de la historia literaria, no sólo destaca la especial configuración del Insólito en la literatura sudamericana, pero también establece la modalidad que contribuyó/e para con la visualización y la representación de la diversidad cultural. Nos valemos de una pesquisa con metodología de cuño bibliográfico que aspira analizar, caracterizar, definir y consignar diferencias pertinentes a las modalidades insólitas en cuestión.

Palabras-clave: Fantástico. Insólito. Real Maravilloso. Realismo Maravilloso. 


\section{Introdução}

Ao desenvolver a discussão teórica sobre as modalidades de produção literária em que o evento insólito irrompe a malha discursiva, faz-se necessário retomar algumas definições do Insólito, ora designando um macrogênero (Cf. REIS, 2001, p. 253) ora uma categoria ficcional. Conforme nosso estudo, consideramos que forma uma classe, um grupo, uma série, capaz de configurar diversas modalidades; ou seja, o Insólito fixa-se como uma categoria cujos traços presentes no texto evidenciam o extraordinário, sobrenatural ou extranatural que, de uma forma ou de outra, causam estranhamento, medo, ou, pelo menos, inquietação no leitor.

Os estudos apontados por Lenira Covizzi (1978), Victor Bravo (1987), Remo Ceserani (2006), Renato Prada Oropeza (2006), Lauro Maurada (2010), Flávio Garcia (2007; 2012) e Heidrun Krieger (2012) sublinham o diálogo das diferenças nos sistemas literários reciprocamente compartilhados, fundados no conhecimento cultural da América do Sul $^{1}$, em que as expressões sobrenaturais, extraordinárias ou extranaturais circundam as diversas modalidades de produção literária. Buscamos, assim, nesta pesquisa, redimensionar, revisar e verificar o que as designa. Logo, torna-se indispensável caracterizar e saber em que se aproximam ou se distanciam: o Fantástico, o Realismo Mágico e, especialmente, o Realismo Maravilhoso.

Nessa perspectiva, recorremos a um feixe de contribuições teóricas quanto ao emprego dos termos citados para, a partir da crítica literária, em ampla maioria, sul-americana, e de sua própria ficção insólita, rasurar sinônimos e desfazer imprecisões instauradas nos estudos estéticos e literários em relação a tais conceituações. A revisão de tal desalinho justifica-se principalmente porque se

\footnotetext{
1 A fim de evitarmos a carga eurocêntrica implicada no termo "América Latina", em seu lugar, assumimos a expressão "América do Sul", contraposta à América do Norte, saxônica. Apesar da divergência cartográfica que essa opção pode implicar, o critério linguístico-cultural e ideológico que adotamos não exclui da América do Sul, nem o México ou a América Central.
}

importam nomenclaturas de outros espaços/áreas que não correspondem a nossa realidade cuja produção literária ainda é catalogada a partir de uma visão eurocentrada.

\section{Desenvolvimento}

A pesquisadora Lenira Marques Covizzi (1978) inicialmente atribui ao Insólito o status de gênero. No entanto, ao concluir seu estudo, afirma ser uma importante categoria, já que não se trata de uma nova característica da arte contemporânea, mas de um traço peculiar da condição de ser ficcional e que motiva no leitor a sensação do "inverossímil, incômodo, infame, incongruente, impossível, infinito, incorrigível, incrível, inaudito, inusitado" (p. 25-26, grifo da autora).

O atributo desestruturador da ordem convencionada, social e culturalmente própria do senso comum, para Covizzi (1978), é um fator relevante do qual fazemos uso para destacar as transformações sofridas pela ficção desde o século XX. Para Renato Prada Oropeza (2006), o Insólito é o componente principal que caracteriza a narrativa fantástica. A aceitação ou não dos eventos insólitos, a relação do leitor com a propriedade insólita, segundo Oropeza (2006), "refere-se aos 'elementos da discursivização', por ele distribuídos em 'temporalização' - aludindo ao tempo -, 'espacialização' - ao espaço -, 'actorialização' - às personagens - e 'níveis de relação pragmática' entre autor e leitor, e narrativa" (apud GARCIA, 212, p. 17).

Para o professor Flávio Garcia (2012), o Insólito decorre daquilo que não é usual, mas que se iguala ao sobrenatural ou extranatural, esquivando-se do que é esperado ou previsível, todavia, contíguo ao estranho, inabitual e imprevisto, dissociado da realidade. Diferentemente de García (2012), Heidrun Krieger (2012), em “Insólito: um termo relacional”, contrapõe ao Insólito sua face sólida que articula e rearticula a concepção de um e do outro; aproxima-os ao mesmo tempo em que os distancia, estabelecendo, assim, uma condição paradoxal. A autora descarta o rótulo 
que marca a propriedade conceitual, no entanto sublinha a condição como experiência estética articulada ao intervalo entre disciplina e diferença, entre norma e surpresa. Segundo a estudiosa, configuram-se paradoxos, mesmo que o evento insólito esteja inserido na realidade sul-americana é visto como algo espalhafatoso, uma vez que contraria os horizontes de expectativa e provoca o desconforto e estranhamento; para ser compreendido, deverá ser reformulado a partir da rejeição ou da reformulação de partes (ou não) das heranças conceituais e culturais.

Para estabelecer a relação do Insólito com a produção literária sul-americana, recorremos aos estudos de Irlemar Chiampi (1980) a respeito do Realismo Maravilhoso. Essa designação inaugura-se a partir do paradigmático prólogo à edição de 1949 do romance do franco-cubano Alejo Carpentier, intitulado El reino de este mundo (1944) e abrange outras narrativas ficcionais de sua autoria, como ¡ÉcueYamba-Ó! (1933), Los pasos perdidos (1949), El acoso (1956), El siglo de las luces (1962), Concierto barroco (1974) e El arpa y la sombra (1979). Assumindo os riscos e as posibilidades de falhas e omissões implicados numa listagem deste tipo, elencamos outros romancistas sul-americanos que contribuem para a consolidação do Realismo Maravilhoso, tais como: o guatemalteco Miguel Ángel Asturias, com El señor Presidente (1946) e Hombres de maíz (1949); os mexicanos Juan Rulfo, com Pedro Páramo (1955); Carlos Fuentes, com Aura (1962), Gringo viejo (1985) e Instinto de Inez (2001); e Laura Esquivel, com o romance Como agua para chocolate (1989); o cubano Lezama Lima, com Paradiso (1966); a chilena Isabel Allende, com La casa de los espíritus (1982), De amor y de sombra (1984) e Eva Luna(1987); os peruanos Manuel Scorza, com Historia de Garabombo, el invisible (1972) e Redoble por rancas (1970); José María Arguedas, com Agua (1935), Yawar fiesta (1941) e Los ríos profundos (1958); Mario Vargas Llosa, com La ciudad y los perros (1963), La casa verde (1966) e Conversación en La catedral (1969); argentino Tomás Eloy Martínez, com Sagrado (1969), La mano del amo (1991), fragmentos realista-maravilhosos dos romances La novela de Perón (1985) e Santa Evita (1995).

Não podemos deixar de mencionar os equatorianos considerados como precursores dessa modalidade narrativa: Demetrio Aguilera Malta, com os romances Don Goyo (1933) e La isla virgen (1942); José de la Cuadra y Vargas, com seus contos "La tigra" (1932), "Banda de pueblo" (1932) e "Los Sangurimas" (1934); também o venezuelano Arturo Uslar Pietri, com seu conto "La lluvia" (1935). Tampouco devemos esquecer o ícone dessa modalidade de produção literária - Gabriel García Márquez -, autor de Cien años de soledad (1967), El otoño del patriarca (1975), Crónica de una muerte anunciada (1981), El coronel no tiene quien le escriba (1961), La mala hora (1962), La hojarasca (1955) e Los funerales de la mamá grande (1962). Ainda importa lembrar que escritores brasileiros também se destacaram em narrativas do mesmo tipo: o goiano José J. Veiga, com O coronel e o lobisomem (1964); os gaúchos Moacyr Scliar, com os contos de Carnaval dos animais (1968) e o romance O centauro no jardim (1980); Érico Veríssimo, Josué Guimarães e Roberto Bittencourt Martins, respectivamente, com as narrativas romanescas Incidente em Antares (1971), Os tambores silenciosos (1977) e Ibiamoré, o trem fantasma (1981).

Convém lembrar ainda que a primeira tradução de um romance hispano-americano no Brasil foi realizada por Jorge Amado. Trata-se de Doña Bárbara (1929), do venezuelano Rómulo Gallegos. O escritor baiano também produziu duas obras de caráter realista maravilhoso: $A$ morte e a morte de Quincas Berro D’água (1961) e O compadre Ogum (1964). Esse traço impregna várias passagens de Dona Flor e seus dois maridos (1966). Outro ficcionista baiano que incursionou pelo Realismo Maravilhoso é João Ubaldo Ribeiro, com alguns contos da compilação Já podeis da pátria filhos (1991), como "O santo que não acreditava em Deus"; várias narrativas de Viva o povo brasileiro (1984) e 0 feitiço da llha do Pavão (1997). 
A correlação com os relatos emblemáticos do $B^{2}{ }^{2}$ literário hispano-americano e seu próprio enraizamento histórico-literário dá-se de forma problemática e repleta de discordâncias, tornando significativa a origem e a formação do povo da América não saxônica na elaboração da sua literatura. $\mathrm{Na}$ apresentação de $\mathrm{O}$ realismo maravilhoso (CHIAMPI, 1980), Emir Rodríguez Monegal enfatiza a importância da América em redescobrimento - no que se refere à história literária - e como o referencial cultural corroborou para o imaginário das obras literárias produzidas nas Américas. Assinala-se a ruptura com a influência europeia a fim de firmar uma identidade literária. Esse espaço sociocultural em que o autor está inserido repercute na(s) personagem(s) e na(s) tessitura(s) narrativa(s); saber e conhecer a realidade de uma civilização é contribuir para com o imaginário do todo artístico, nesse caso, a obra literária.

Instaura-se assim uma modalidade de produção narrativa peculiar à América do Sul. Chiampi (1980) expõe, inicialmente, o uso equivocado do termo "Realismo Mágico" à produção literária sulamericana, termo atribuído à classificação e/ou caracterização das artes plásticas. Segundo a autora, um grande erro ou, pelo menos, uma inadequação na tentativa de rotular nossa obra literária. A partir do conceito de "mágico", Chiampi (1980) estabelece uma discussão para definir em que esse termo se diferencia de "maravilhoso" e como as diferenças e as

\footnotetext{
2 Movimento literário que ocorreu por volta do ano de 1960, coincidentemente, em paralelo com os efeitos da Revolução Cubana. No entanto, a crise cultural sul-americana surgiu desde a Guerra Espanhola e a Segunda Guerra Mundial, sendo que a ruptura mais significativa é a das vanguardas dos anos 1920 . Segundo Emir Rodríguez Monegal (1979), "de um lado, cada crise rompe com a tradição e se propõe instaurar uma nova estimativa, por outro, cada crise escava no passado (imediato ou remoto) para legitimar sua revolta, para criar uma árvore genealógica, para justificar a estirpe" (p. 131). Por volta de 1960, um seleto grupo de romancistas, dentre eles, Carlos Fuentes, Gabriel García Márquez, Júlio Cortázar e Mario Vargas Llosa, relativamente jovens, divulga na Europa e no resto do mundo uma narrativa que inclui ficção, degradação, difusão, controle autoral e uma incansável experimentação (SOMMER, 2004, p. 16). A nova narrativa produzida na América destacava a história e buscava mostrar aos europeus que aqui também existia literatura de qualidade, não era um território onde apenas aconteciam "golpes de estados e domavam-se potros" (CORTÁZAR, 1973, p. 15). Conforme Doris Sommer (2004), "os novos romancistas [...] delineiam a densidade histórica sobre um mapa repleto de projetos mutilados" (p. 44). O Boom não foi somente um fenômeno comercial promovido pelas editoras, oportunizou o apoio às revoluções e aos projetos socialistas na América do Sul.
}

possíveis similaridades podem contribuir para a construção do conceito de Realismo Maravilhoso.

Com o intuito de desfazer a polêmica, a estudiosa destaca o termo "Real Maravilhoso Americano", estabelecido por Alejo Capentier (1968) ${ }^{3}$ no já mencionado prólogo, escrito em 1949, de sua obra literária El reino de este mundo e assinala as relações da narrativa realista maravilhosa com a cultura sul-americana evidenciada nos eventos insólitos que a reestabelecem e a reconstroem, ressignificando o texto romanesco. Desse modo, Chiampi (1980) instaura dois níveis importantes para a definição do que Carpentier (1968) chama de "Real Maravilhoso Americano":

1ำ - É constituído pelo modo de percepção do real pelo sujeito;

$2^{\circ}$ - pela relação entre a obra narrativa e os constituintes maravilhosos da realidade americana.

Assim como Chiampi (1980), Louis Philippe Dalembert (2013), estudioso haitiano, recorre a Alejo Carpentier e enfatiza como a experiência cultural do autor colabora com o imaginário, portanto não se perde de vista a importância do contexto sociocultural para a configuração da obra literária hispanoamericana. O romance torna-se representativo dessa realidade sul-americana, ou seja, cultura, espaço e tempo dialogam em seu universo ficcional.

A contribuição de Carpentier consiste nesse diálogo cultura-espaço-tempo e na identificação da identidade hispano-americana com traços étnicos e históricos que, de certa forma, são estranhos aos padrões racionais europeus, mas característicos de uma realidade identificada como maravilhosa e real ao mesmo tempo. Dalambert (2013) afirma que a diversidade cultural sul-americana se faz presente não só na conceituação do termo Real Maravilhoso,

\footnotetext{
${ }^{3}$ O Real Maravilhoso, expressão cunhada por Alejo Carpentier, corrobora com o conceito de Realismo Maravilhoso. Carpentier passa anos estudando a América, motivado pela crise pessoal em busca de uma consciência americana e reforçada por sua experiência surrealista na França. De acordo com Irlemar Chiampi, Carpentier usa essa expressão, no prólogo escrito em 1949, para designar "não as fantasias ou invenções do narrador, mas o conjunto de objetos e eventos reais que singularizam a América no contexto ocidental" (p. 32).
} 
mas, principalmente, na elaboração de uma modalidade de produção narrativa própria do romance da América do Sul. O Real Maravilhoso é basilar para o Realismo Maravilhoso, mas não são sinônimos, pois enquanto o primeiro está diretamente ligado à cultura (fonte inspiradora), o segundo designa uma modalidade narrativa influenciada por esse manancial e, pois, presente na escrita literária hispano-americana.

Com o Boom, a produção literária sulamericana ganha espaço no cenário internacional, no entanto recebe o rótulo de uma literatura com característica do chamado Realismo Mágico. A utilização do termo que classifica nossas obras literárias é universalizada e imprópria, segundo Chiampi (1980), já que estabelece certa imprecisão e inadequação.

Antonio R. Esteves e Eurídice Figueiredo (2010, p. 411) associam-se à proposição de Chiampi (1980) e, em seu estudo, comentam o texto "Magic Realism: a Typology", de 1993, de William Spindler, que apresenta uma tipologia a partir de duas acepções. A primeira atribui ao Realismo Mágico a condição de estilo: o natural e o comum são compreendidos como sobrenaturais, por meio de uma construção que retira 0 sobrenatural como significação própria. Já a segunda interpretação vai ao encontro do Real Maravilhoso Americano de Carpentier, contudo os autores advertem que uma boa parte da crítica literária usa o Realismo Mágico como sinônimo do Realismo Maravilhoso, o que promove significativa ambiguidade devido ao uso indiscriminado dos dois termos. Insistindo na utilização do termo, Willian Spindler (apud ESTEVES; FIGUEIREDO, 2010, p. 412) sugere três modalidades para o Realismo Mágico:

I - Realismo mágico metafísico: mais apropriado à pintura, podendo ser aplicado na literatura desde que mostre perspectivas deslocadas e ângulos incomuns, induzindo a um efeito de irrealidade, no entanto, sem relacionar-se com o sobrenatural.

II - Realismo mágico antropológico: 0 narrador normalmente tem duas vozes, uma que usa o ponto de vista racional e outra que dá ênfase à magia, a qual está relacionada aos mitos e culturas de um grupo étnico ou social.

III - Realismo mágico ontológico: o sobrenatural é percebido como se não contradissesse a razão e não se oferecem explicações para os acontecimentos irreais presentes na narrativa. Difere do Fantástico no sentido de que o receptor não se altera ou se perturba diante do fato apresentado.

Essa classificação do Realismo Mágico proposta por Spindler (apud ESTEVES; FIGUEIREDO, 2010) é categoricamente descartada por Chiampi (1980), devido à sua amplitude no que diz respeito à produção discursiva presente no romance sul-americano, além de ser formada por termos antagônicos que sugerem ideias opostas (real $x$ mágico). Já o termo Realismo Maravilhoso caracteriza de forma clara e precisa a narrativa sulamericana, uma vez que vem imbuída de mitos e tradições pertencentes ao âmbito sociocultural do continente.

Esteves e Figueiredo (2010) afirmam, ainda, que o Realismo Mágico constitui uma tentativa homogeneizadora no que diz respeito a classificar uma literatura tão heterogênea, multifacetada e complexa como é a sul-americana. A variedade conceitual e, muitas vezes, incompatível, segundo os estudiosos, alimenta essa vontade equalizadora vinculada à utopia de uma única e grande América. No entanto, a tendência é que tais conceitos adquiram outros matizes, mais próximos da nossa realidade multicultural.

Além do Realismo Maravilhoso, destacamos outra modalidade pertencente ao Insólito: o Fantástico. O argentino Eduardo Ladislao Homlberg já se pronunciava no Rio da Prata com a narrativa fantástica La pipa de Hoffman (1876), ainda que o escritor mais popular desse espaço e em tal modalidade viesse a ser o contista uruguaio Horacio Quiroga, com "El almohadón de plumas" (1907), "Los guantes de goma" (1909), "Más allá" (1935), dentre outros contos marcantes. Voltando a assumir a mesma possibilidade de deixarmos lacunas, e talvez impropriedades, já que seguimos as denominações fornecidas pela crítica literária, sem que pudéssemos estudar caso a caso, apresentamos o seguinte elenco de ficcionistas que também contribuíram com o Fantástico: o mexicano 
José Joaquín Fernández de Lizardi, com o Periquillo Sarniento (1816) e La Quijotita y su prima (1818); o uruguaio Felisberto Hernández, com Nadie encendía las lámparas (1947), La hortensias (1949), La casa inundada (1960) e El cocodrilo (1967).

No entanto, a modalidade fantástica do Insólito assinalou significativa presença no cenário literário a partir dos renomados escritores argentinos: Adolfo Bioy Casares, com o romance La invención de Morel (1940) e o conto "En memoria de Paulina" da antologia La trama celeste (1948); Jorge Luis Borges, com a antologia de narrativas curtas Ficciones (1944); Julio Cortázar, com os contos "Casa tomada" (1946), "La noche boca arriba" (1956), "Las babas del diablo" (1959) e "Continuidad en los parques" (1964), dentre outras produções narrativas. Um significativo conjunto de escritores sobressai na ficção fantástica, tais como os argentinos Arturo Cancela, Carlos Peralta, Héctor Álvarez Murema, José Bianco, Juan Rodolfo Wilcock, Leopoldo Lugones, Macedonio Fernández, Manuel Peyrou, Pilar de Lussarreta, Santiago Dabove e a mexicana Elena Garro. Alguns dos contos desses ficcionistas, assim como os de Bioy Casares, Borges e Cortázar, foram reunidos e publicados na Antología de la literatura fantástica (1965), organizada por Bioy Casares, Borges e Silvina Ocampo.

Como aporte uruguaio, apontamos os escritores e organizadores da compilação Cuentos fantásticos del Uruguay (1999) Hebert Benítez Pezzolano, Laura Fumagalli e Sylvia Lago, com produções de Ana Solari, Armonía Somers, Francisco Espíndola, Héctor Galmés, Jaime Monestier, Juan Introini, Leonardo Garet, Marosa di Giorgio, Miguel Ángel Campodónico, Rafael Courtoisie, Ruben D'Alba, dentre outros. Antología del cuento fantástico (1967), de Roger Caillois, também reúne grandes escritores da América não franco-saxônica como: os cubanos Alejo Carpentier, Germán Piniella e Virgilio Piñera; os chilenos Alexandro Jodorowsky, Juan Emar, e María Luisa Bombal; os mexicanos Amado Nervo, Alfonso Reyes, José Emilio Pacheco, Juan José Arreola e Juan Rulfo; o venezuelano Arturo Uslar Pietri; o hondurenho Augusto Monterroso; o panamenho Carlos Fuentes; os peruanos César
Vallejo, Clemente Palma e Julio Ramón Ribeyro; os argentinos Enrique Anderson Imbert e Manuel Mujica Lainez. No Brasil, contamos com o contista mineiro Murilo Rubião, em $O$ pirotécnico Zacarias e outros contos (2006), assim como outras produções fantásticas de sua autoria; também com as narrativas curtas do escritor sul-rio-grandense Josué Guimarães, reunidas em O cavalo cego (1979).

A fim de entender a narrativa fantástica, a partir de especificidades e interações socioculturais, próprias da América do Sul, baseamo-nos na proposição de Irène Bessière (1974) que, em "El relato fantástico: forma mixta de caso y adivinanza", ressalta a dificuldade em abordar o Fantástico, visto que pressupostos metodológicos e conceituais préestabelecidos impossibilitam situar e definir seu espaço literário. Para Jean Bellemin-Nöel (apud BESSIÈRRE, 1974, p. 1), o relato fantástico é uma forma de contar, de colocar em evidência o fantasmagórico. Essa definição simplista, conforme a estudiosa, desabilita toda carga semântica sugerida num relato que muitas vezes é sobrenatural ou extranatural e ignora o acervo cultural que permeia a narrativa fantástica. Segundo a autora,

[...] o relato fantástico provoca insegurança, pois coloca em ação dados contraditórios, reunidos segundo uma coerência e uma complementaridade próprias. Não define uma qualidade atual de objetos ou de seres existentes, nem constitui uma categoria ou um gênero literário, mas supõe uma lógica narrativa que é tanto formal quanto temática e que reflete, de forma surpreendente ou arbitrária para o leitor, sob o aparente jogo da invenção pura, as metamorfoses culturais da razão e do imaginário coletivo (p. 2, tradução nossa) ${ }^{4}$

Bessière (1974) trata de esclarecer as especificidades que compõem o Fantástico. Não acata o conceito de categoria ou gênero literário, mas propõe que seja tomado como procedimento narrativo

\footnotetext{
4 Texto original: "el relato fantástico provoca inseguridad, porque pone en funcionamiento caracteres contradictorios reunidos de acuerdo a una coherencia y una complementariedad propias. No define una calidad actual de objetos o de seres existentes, y tampoco constituye una categoría o género literario, sino que supone una lógica narrativa a vez formal y temática que refleja, de manera sorprendente o arbitraria para el lector, tras el aparente juego de la invención pura, las metamorfosis culturales de la razón y del imaginario colectivo" (BESSIĖRE, 1974, p. 2).
} 
que descreve o universo real de forma contraditória e inverossímil. O raciocínio não é acionado para reconstruir a continuidade, mas para promover a quebra de um silêncio proposto pela verossimilhança, rescindindo o discurso comum pré-estabelecido e a originalidade absoluta dos fatos.

Na narrativa fantástica, a veracidade é tratada a partir da falsidade e da multiplicidade inseridas no corpo da tessitura literária, propondo um simples mistério ou um enigma a ser decifrado. Não se oferece solução para a resolução da incógnita, instaura-se a dúvida, o vacilo, o medo e, em alguns casos, o terror. Segundo Bessière (1974), "a sequência das explicações não conduz jamais a uma explicação única, cada proposta de solução invoca sua própria explicitação, cuja ausência apontaria para a inverossimilhança" (p. 9, tradução nossa) ${ }^{5}$. Essa hesitação própria do Fantástico não acontece no Realismo Maravilhoso, modalidade em que 0 sobrenatural é naturalizado (neutralizado), o real e o maravilhoso coabitam, o Insólito se faz reconhecido no contexto sociocultural ao qual o sujeito pertence; as explicações para os eventos representados na obra literária encontram-se no universo real e maravilhoso do leitor.

Outros teóricos, como Remo Ceserani (2006) e Lauro Marauda (2010), a fim de corroborar para a definição do Fantástico como modalidade narrativa, recorrem aos estudos de Tzvetan Todorov (2003) que, em Introducción a la literatura fantástica, entende-o como um gênero narrativo que associa a realidade ao maravilhoso e propõe uma dúvida ao narrador que, por sua vez, comunica ao leitor. A literatura fantástica, segundo Todorov (2003), apresenta a ambiguidade percebida pelo leitor no que se refere aos acontecimentos relatados.

A partir da contribuição de Todorov (2003), Marauda (2010) pressupõe a polêmica instaurada na definição do Fantástico e na sua aplicação como termo caracterizador de uma produção narrativa. A princípio, o autor uruguaio busca diferenciar o que é

\footnotetext{
5 Texto original: "la secuencia de explicaciones no conduce, jamás a una explicación, toda propuesta de solución necesita su propia explicación, si ésta no existiera, la solución pasa a lo inverosímil' (BESSIÈRE, 1974, p. 9).
}

expressivo e torna uma narrativa sobrenatural ou maravilhosa; constituir tal diferenciação torna-se significativa para a compreensão dos conceitos. Nesse sentido, concebe o Maravilhoso como algo natural, pois a personagem não se surpreende nem se assusta com o evento insólito apresentado, diferentemente do que acontece com o Sobrenatural, que explana um relato em que os protagonistas são seres sobrenaturais, vampiros, lobisomens, superheróis.

Mesmo destacando em que diferem as modalidades Maravilhoso e Sobrenatural, Marauda (2010) traz a similaridade que permeia tais conceitos. Tanto uma quanto outra se referem a fatos que nunca ocorreram, nem poderão ocorrer, sua aceitação é acatada pelo leitor consciente da impossibilidade da ocorrência sobrenatural ou maravilhosa. Estabelecer limites entre o que representa a realidade e o que pode ser considerado como pertinente ao ficcional faz com que o teórico se apegue a uma conceituação simplista do Fantástico. O estudioso uruguaio afirma que todo relato em que seres sobrenaturais surgem na atmosfera cotidiana pertence a essa modalidade.

Porém, os teóricos Antonio Risco, PierreGeorges Castex, Louis Vax, Montague Rhode James, Olga Reimann, Roger Caillois, e Vladimir Soloviov, segundo o estudo de Marauda (2010), consideram que o Fantástico entra com ímpeto no cotidiano, provocando a inquietação da personagem e do leitor, de maneira mais ou menos contundente. Portanto, o que vai configurá-lo é a relação entre a narrativa e a recepção. Na narrativa fantástica, questionamentos são levantados e os relatos podem gerar dúvidas, estranhamento e até mesmo medo, mas em nenhum momento o leitor (e/ou personagem) encontra respostas ou atribui à sua realidade o que está narrado, mesmo porque a explicação será inexistente, já que se criam mundos e personagens onde as leis naturais (desse mundo) não operam.

A produção literária do Insólito, segundo o estudioso, em alguns momentos insere silêncios e objetos que, mesmo incríveis e ficcionais, atribuem de alguma forma uma explicação sobrenatural ao evento, a narração cria conteúdos que dependem da vontade 
do narrador. O leitor tem a condição de atribuir um final para o que foi narrado, mas nunca terá certeza da conclusão da história. Haver explicação ou fato que preencha uma lacuna deixada proposital e intencionalmente pelo autor faz com que essa produção deixe de ser fantástica, já que a realidade passa a vigorar dentro do meio criado pela tessitura narrativa. O Fantástico, desse modo, está diretamente ligado ao inexplicável.

Ítalo Calvino, mencionado em Panorama de la narrativa uruguaya (MARAUDA, 2010), coopera com o entendimento do Fantástico e com os mecanismos de criação dessa modalidade narrativa. Para Calvino (2010), o Fantástico elabora a ideia de que acontecimentos inexplicáveis surgem no cotidiano como gretas que incomodam e levam o receptor a lugares inimagináveis onde $o$ irreal se funde $e$ confunde com o real.

Já Remo Ceserani (2006) atribui ao termo Fantástico a característica de modalidade de produção narrativa que pressupõe procedimentos, técnicas e temáticas. Desse modo, os conceitos e as relações estabelecidas entre Fantástico e Realismo Maravilhoso ajudarão a observar as representações da realidade, da casualidade e do Insólito. O modo Fantástico, conforme Ceserani (2006), encontrado geralmente em obras literárias mimético-realistas, patético-sentimentais, aventurescas, fabulosas, cômico-carnavalescas, entre outras, organiza essa estrutura representativa e transmite, de forma impactante e singular, vivências inquietantes ao leitor.

Em O fantástico, Ceserani (2006) também menciona a proposta de Todorov (2003) ao subdividir - Insólito por discurso narrativo: o Maravilhoso, o Maravilhoso-Fantástico, o Fantástico, o FantásticoEstranho e o Estranho. Lucio Lugnani contesta essa subdivisão e apresenta três pontos relevantes para o presente estudo. $O$ primeiro refere-se às duas categorias do Maravilhoso e do Estranho, pois essas não são simétricas nem homogêneas; o estranho é relativamente restrito, relacionado ao Maravilhoso. 0 segundo ponto diz respeito à inadequação de se constituírem como gêneros literários, já que o Estranho, nesse contexto, é caracterizado por significados contrários e o Maravilhoso, por sua vez, estabelece a aceitação plena do sobrenatural, o que caracteriza muitos gêneros literários. Por último, Lugnani destaca que Todorov cria dissimetria e heterogeneidade entre as duas categorias, pois uma assinala a emoção suscitada nas personagens e no leitor e na outra, essa emoção materializa-se por meio da natureza dos acontecimentos narrados.

Portanto, a partir das contribuições de Lugnani, Ceserani (2006), conclui que uma definição como essa (modo de contar e não um gênero narrativo) é:

fundamentada em elementos de análise formal, de enquadramento cultural e em uma concepção mais ampla dos modos literários, resultam bastante limitadas as definições que tendem a substituir a sutil diferença entre as cinco categorias de Todorov [...], ou as cinco de Lugnani (o realista, o fantástico, o maravilhoso, e estranho e o surrealista), com uma diferença forte e clara entre apenas duas categorias, colocando de um lado o realista e de outro um amplo conjunto, constituído pelo fantástico e maravilhoso (p. 57).

Em Narrativas fantásticas de Borges e Rubião: insólitos que se bifurcam a caminho do leitor, Elisângela dos Reis Oliveira (2010) parte das leituras de Ceserani (2006), Marauda (2010) e Todorov (1970), a fim de elaborar um percurso do estudo sobre o Fantástico. A pesquisa contribui para entendermos como a imaginação do escritor, as personagens e o "leitor implícito" contribuem com o relato insólito. Segundo Oliveira (2010), o modelo de realidade contido na tessitura fantástica incide em categorias modais; a concepção de real é produto de uma convenção social, adquirida a partir das experiências linguístico-culturais impregnadas pelos câmbios históricos de uma determinada sociedade; desse modo, estabelece-se a relação entre autor/narrador, texto e leitor.

A pesquisa de Oliveira (2010) comprova a presença do Insólito como dispositivo de reflexão sobre o texto literário e o escritor, instaurando uma questão relevante a respeito do Fantástico: a alteridade. Segundo Victor Bravo (1987), trata-se de um traço próprio da narrativa fantástica. questionamento do real perante o texto literário subordina-se a uma razão de ser no mundo, como 
uma máscara, ou estabelece uma dissociação que Ihe propõe rasurar signos, miragens e verdades. A alteridade, segundo Bravo (1987), é constituída a partir da tentativa dessa negação ou aprofundamento da complexa subordinação ou separação referente ao real, a fim de refletir sobre e/ou questionar a realidade proposta no limiar estabelecido com a ficção.

Para o estudioso venezuelano, a alteridade é uma maneira de expressar através da linguagem uma realidade outra, vista com um olhar motivado "não pelo reflexo do 'mesmo' (dos referentes do mundo) senão que por essa expressão do 'outro', do estranho, que é o sobrenatural e sagrado" (BRAVO, 1987, p 22, tradução nossa) ${ }^{6}$. A realidade criada por esse olhar desloca o "eu" e permite que o Fantástico problematize o que é verossímil. Segundo Chiampi (1980), na narrativa realista maravilhosa, o Insólito aparece, de um lado, como produto da concepção deformadora do sujeito; de outro, pode compor a realidade. Já o Fantástico, a autora o define como um princípio psicológico garantido pela percepção estética, a fantasticidade, que é, fundamentalmente, uma forma de produzir no receptor essa inquietação (o medo e suas variantes), através de uma motivação intelectual (a dúvida).

A diferença entre o Fantástico e o Realismo Maravilhoso reside não só no fato de o primeiro depender da criatividade narrativa do autor, pois cria e recria mundos reais e/ou ficcionais sem a intenção de convencer seu leitor da existência do evento insólito narrado; o receptor o acata como ficcional e, principalmente, como algo sobrenatural. Já o Realismo Maravilhoso depende da moldura contextual, uma vez que as narrativas literárias próprias dessa modalidade do Insólito apresentam como característica a faculdade de representar a cultura. Chiampi (1980) afirma que o Realismo Maravilhoso não exclui os realia (índices de realidade) do texto, mesmo que o espaço-temporal

\footnotetext{
6 Texto original: "el reflejo de lo mismo (de los referentes del mundo) sino por esa expresión de lo 'otro', de lo extraño, que lo sobrenatural y lo sagrado (BRAVO, 1987, p. 22).
}

seja indefinido, e não foge, não deixa claro ou não questiona a causalidade.

Essa conceituação é dada a partir da diferença na utilização das expressões que caracterizam a literatura hispano-americana, pois segundo a estudiosa, o Realismo Maravilhoso reestabelece a realidade sem explicitá-la, mas difundindo-a. Já o Fantástico gera conflito ou embate com o que é considerado real. A descontinuidade entre causa e efeito é característica na escrita realista maravilhosa, ao contrário do que acontece na fantástica. 0 Realismo Maravilhoso:

propõe um 'reconhecimento inquietante', pois o papel da mitologia, das crenças religiosas, da magia e das tradições populares consiste em trazer de volta o 'Heimliche,7, o familiar coletivo, oculto e dissimulado pela repressão da racionalidade. [...] o realismo maravilhoso visa tocar a sensibilidade do leitor como ser da coletividade, como membro de uma (desejável) comunidade sem valores unitários e hierarquizados (CHIAMPI, 1980, p. 69).

Desse modo, o olhar do leitor não será o de um estranho àquela realidade e sim, uma mirada que concebe e conhece (ou não) o que é maravilhoso dentro de sua vivência como indivíduo. Os "efeitos emotivos", a saber, inquietação física, psicológica e/ou intelectual (dúvida, medo e suas variantes), provocados pela narrativa, neutralizam-se (ou se negam) no Realismo Maravilhoso, já que essa modalidade retira o medo e suas variantes do relato insólito. Chiampi (1980) explana as acepções dadas ao termo "maravilhoso" e propõe duas significações. A primeira associa-se ao léxico da expressão mirabilia latina, com sentido de olhar, mirar atencioso, relacionase à etimologia, o milagre ou a miragem, fugindo ao convencional, ao natural. Já a segunda significação

\footnotetext{
7 Unheimlich (estranho, sinistro) deu título a um famoso ensaio de Freud de 1919: "O estranho". "Um dos sentidos de unheimlich, como o próprio Freud destacou, é justamente o de unbehaglish (o que provoca mal-estar). Se de certo modo podemos dizer que a psicanálise procedeu à revelação do Unheimlich da psique do indivíduo, ou seja, revelou 'tudo aquilo que deveria ter permanecido em segredo e oculto e veio à luz' (na definição do filósofo idealista Schelling, aprovada por Freud), no caso deste ensaio de 1930 Freud procura mostrar o oculto, o segredo, por detrás de toda cultura e da nossa humanidade, ou seja, seu malestar e suas origens mais profundas" (SELIGMANN-SILVA, 2010, p. 25) Logo, heimlich é tudo aquilo que permanece secreto, oculto, pertencente à casa, familiar, doméstico, íntimo, algo escondido, secreto, oculto.
} 
elabora-se na diferença não qualitativa com o humano, dotado de exagero, do inabitual; no entanto, belo e possível de ser admirado pelo sujeito.

A função textual dessa modalidade narrativa se estabelece no "efeito de encantamento" suposto pela função do leitor perante a função do narrador/ personagem e que está presente na significação discursiva atribuída à obra literária. Segundo Chiampi (1980), para a análise da narrativa sul-americana, é necessário que se admitam dois planos operacionais - do relato e do discurso - evidentes nas maneiras por meio das quais os eventos de cunho realista maravilhoso são narrados ou descritos.

\section{Considerações finais}

Os elementos insólitos, para todos os estudiosos citados no decorrer desta pesquisa, marcam presença tanto no Realismo Maravilhoso, lembrando que esse é produto do Real Maravilhoso Americano, quanto no Fantástico. Já ao Realismo Mágico, atribui-se a condição de simples rótulo, uma vez que, essa suposta legenda não desvenda, não contribui para com a multiplicidade sociocultural da América do Sul nem dá conta do que se considera Maravilhoso ou Fantástico. Os seres representados nas obras literárias de caráter realista-maravilhoso configuram a cultura, o folclore, as crenças, os mitos e ritos; já os seres fantásticos são constituídos a partir das inquietações lançadas ao leitor; a interação entre texto e leitor é proposta por: hesitação, dúvida, medo, silêncio. No que se refere ao Mágico, em sentido lato do vocábulo, o "ilusionismo" não ocorre nas narrativas do contexto da América do Sul, já a magia, a feitiçaria, a bruxaria essa sim tem lugar apropriado no espaço literário sul-americano.

Para tanto, baseados em Chiampi (1980), compactuamos com as relações pragmáticas, semânticas e discursivas, que não determinam somente um movimento literário específico de uma época e/ou espaço sul-americano, mas, principalmente, permitem-nos identificar uma forma discursiva marcada pelas associações socioculturais independentes do espaço e do tempo. Valemo-nos da crítica e do estudo literário sul-americanos para embasar nossa discussão, pois, conforme Krieger (2012), os estudiosos da atualidade são unânimes no que diz respeito à inadequação ao analisar as obras literárias apartados de seus agentes e de seu contexto sociocultural. O ideal, segundo as já citadas teóricas Chiampi (1980) e Krieger (2012), é analisar o texto favorecendo a (re)construção de uma teia interativa estabelecida com o leitor, visto como sujeito integrante de uma determinada sociedade relacionada à sua realidade (pluri)cultural.

Nesse sentido, consentimos que as duas modalidades de produção narrativa, Realismo Maravilhoso e Fantástico, autorizam um discurso assinalado pela combinação entre a realidade (sociocultural) e a ficção e que, por intermédio do narrador, objetiva manter um diálogo com o leitor. A malha discursiva se desenvolve a partir das experiências culturais, históricas e sociais que se articulam com o sujeito, o mundo ficcional e/ou Insólito presente na obra literária.

A ideia dos teóricos em estudo não é apresentar o Realismo Maravilhoso como o representante mais significativo na produção literária da América do Sul, mas, simplesmente, diferenciá-lo do Fantástico, uma vez que, elaborado na tessitura narrativa sul-americana, a escrita realista maravilhosa atende a uma das mais ricas hibridações culturais, sem levar em conta somente a diversidade de etnias; consideram os teóricos referidos no presente estudo que o mais importante e a ser destacado nessa modalidade é a diversidade cultural fundida na nossa vida e literatura. Nessa perspectiva, Chiampi (1980) afirma que a união dos elementos multiculturais próprios da nossa realidade se distancia do olhar eurocentrado. A fantasia, a mágica ou, ainda, as construções discursivas elaboradas pelo escritor não são concebidas para forjar as "falsas maravilhas" do continente americano.

$\mathrm{Na}$ verdade, a produção literária sul-americana diz respeito a uma série de elementos reais singulares. Zilá Bernd (1998) estabelece que a relação entre o narrador e a representação do real não é contraditória já que associa o real e ao maravilhoso. O Real 
Maravilhoso marca presença na narrativa realista maravilhosa e desbrava "os caminhos que levam à construção de um primeiro nível de hibridação onde se associam tradição e visão maravilhosa da realidade a elementos da cultura letrada" (BERND, 1998, p. 44). A caracterização e reconhecimento do Realismo Maravilhoso como uma das modalidades narrativas do Insólito, além de estabelecer as diferenças/similaridades, como discutido anteriormente (o Fantástico ou mesmo o modo chamado, equivocadamente, de Realismo Mágico) propicia compreender uma das maneiras ainda recorrentes pelas quais a literatura da América do Sul se torna representativa de sua diversidade étnico-cultural.

Por fim, concluímos que o Fantástico sulamericano ganhou espaço em centros urbanos marcados pela imigração europeia, portanto, já familiarizados com o Fantástico europeu e mais aproximados aos ideais de La ciudad letrada ${ }^{8}$. Já o Realismo Maravilhoso carrega marcas da herança sociocultural indígena e africana, repleta de ritos e mitos, pautada pelo real e pelo maravilhoso. Logo, o modo particular de conceber ficcionalmente insólitos espaços, eventos, figuras e temporalizações, acaba por impregnar outras literaturas numa produtiva mostra das trocas culturais que parecem nortear desejos de artistas e intelectuais situados às margens e nas periferias do centro euro-americano.

\footnotetext{
${ }^{8}$ La ciudad letrada (1984), de Ángel Rama, ensaio publicado postumamente, destaca a cultura como elemento fundamental no discurso da América do Sul, permitindo entendê-lo como representação sócio-histórica-cultural. Diversas são as leituras feitas, a partir do texto de Rama (1984), contudo, o impasse entre língua e poder, assinalado pelas relações entre os letrados e as estruturas de poder, atravessa a discussão proposta pelo estudioso ao afirmar que "o célebre grupo de religiosos, administradores, educadores, profissionais, escritores e diversos servidores intelectuais, todos aqueles que manipulavam a pena, estavam estreitamente associados às funções de poder e compunham o que Georg Friederici viu como um país modelo de funcionalismo e de burocracia" (RAMA, 1984, p.32, tradução nossa). Nesse sentido, a escrita torna-se relevante para a organização urbana; caso contrário, inviabilizaria a concepção da cidade colonial, uma vez que não haveria leis, administração ou, ainda, hierarquia religiosa. Segundo Rama (1984), o mais significativo foi "a capacidade que demonstraram para se institucionalizar a partir de suas funções específicas [donos das Letras] procurando tornar-se um poder autônomo, dentro das instituições a que pertenceram: audiências, capítulos, seminários, colégios, universidades" ( $p$. 35, tradução nossa). Desse modo, os signos, as palavras desses homens letrados configuram mecanismos inerentes à permanência do poder constituído.
}

De tal forma, escritores brasileiros de uma região com fortes expressões culturais africanas, como Jorge Amado e João Ubaldo Ribeiro, produzem narrativas que se inserem no Realismo Maravilhoso. Tão periférica quanto a literatura baiana em relação ao cânone nacional, a literatura sul-rio-grandense também apresenta expressivo número de ficcionistas que se desempenham na escrita de caráter realistamaravilhoso. A despeito da imigração europeia que assinala o Rio Grande do Sul, assim como a Argentina e o Uruguai, no estado sulino, há registros de literatura fantástica, mas não com a mesma dominância verificada no Rio da Prata. Entretanto, isso talvez constitua matéria para outro estudo, que possa considerar cada uma das obras literárias referidas no presente artigo cuja proposta é mais teórica do que analítica.

\section{Referências}

BENÍTEZ, Hebert Pezzolano; FUMAGALLI, Laura; LAGO, Sylvia. Cuentos fantásticos del Uruguay. Montevideo: Colihue-Sepé, 1999.

BERND, Zilá. "O maravilhoso como ponto de convergência". Revista do Instituto Estadual do Livro Continente Sul Sur, ano 2, n 7, p. 43-59, 1998.

BESSIĖRE, Irène. "El relato fantástico: forma mixta de caso y adivinanza" In: BESSIĖRE, Irene. Le récit fantastique. La poétique de l'incertain. Paris: Larousse, 1974. p. 1-24.

BIOY CASARES, Adolfo; BORGES, Jorge Luis; OCAMPO, Silvina. Antología de la literatura fantástica. Buenos Aires: Debolsillo, 2013.

BORGES, Jorge Luis. Ficciones. Madrid: Alianza editorial, 2005

BRAVO, Víctor. Los poderes de la ficción. Caracas: Monte Ávila Editores Latinoamericana, 1987.

CARPENTIER, Alejo. El reino de este mundo. 3. ed. Montevideo: Arca, 1949.

CAILLOIS, Roger. Antología del cuento fantástico. Buenos Aires: Sudamericana, 1967.

CESERANI, Remo. O fantástico. Tradução de Nilton Cezar Tridapalli. Curitiba: Ed. da UFPR, 2006.

CHIAMPI, Irlemar. O realismo maravilhoso. São Paulo: Perspectiva, 1980. 
DALEMBERT, Louis Philippe. Espaços do imaginário latino-americano: o real maravilhoso de Alejo Carpentier. Trad. de André Mitidieri e Rodrigo dos Santos Mota. In: SILVA, Denise Almeida (Org.). Poéticas do espaço, geografias simbólicas, Frederico Westphalen, URI, 2013. p. 61-76.

ESTEVES, Antonio R.; FIGUEIREDO, Eurídice. O realismo mágico e o realismo maravilhoso. In: FIGUEIREDO, Eurídice (Org.). Conceitos de literatura e cultura. Juiz de Fora, EdUFJF, 2010. p. 393-414.

GARCIA, Flavio. "Quando a manifestação do insólito importa para a crítica literária". In: GARCIA, Flavio; BATALHA, Maria Cristina (Orgs.). Vertentes teóricas do insólito. Rio de Janeiro: Caetés, 2012. p. 13-29.

KRIEGER, Heidrun. "Insólito: um termo relacional". In: GARCIA, Flavio; BATALHA, Maria Cristina (Orgs). Vertentes teóricas do insólito. Rio de Janeiro: Caetés, 2012. p. 39-46.

MARAUDA, Lauro. Panorama de la narrativa uruguaya. Montevideo: Rumbo, 2010.

OLIVEIRA, Elisângela dos Reis. Narrativas fantásticas de Borges e Rubião: insólitos que se bifurcam a caminho do leitor. 2010. 109 f. Dissertação (Mestrado em Letras: Linguagens e Representações) Programa de Pós-Graduação em Letras. Universidade Estadual de Santa Cruz, Ilhéus. 2010.

RAMA, Ángel. La ciudad letrada. Hanover: Ediciones del Norte, 1984.

RIBEIRO, João Ubaldo. Já podeis da pátria filhos e outras histórias. Rio de Janeiro: Objetiva, 2009.

RODRÍGUEZ MONEGAL, Emir. Lo real y lo maravilloso en El reino de este mundo. Revista Iberoamericana, Universidade de Pittsburgh, v. XXXVII, n. 76-77, p. 619-649, jul./dez. 1971.

SELIGMANN-SILVA, Márcio. Prefácio: a cultura ou a sublime guerra entre Amor e Morte. In: FREUD, Sigmund. O mal-estar na cultura. Trad. de Renato Seligmann-Silva. Porto Alegre, RS: L\&PM, 2010. p. 21-38.

TODOROV, Tzvetan. Introdução à literatura fantástica. Trad. de Maria Clara Correa Castelo. São Paulo: Perspectiva, 2003. 